\title{
Functional defects of CD46-induced regulatory T cells to suppress airway inflammation in mite allergic asthma
}

\author{
Yi-Giien Tsai ${ }^{1,2}$, Dau-Ming Niu ${ }^{3}$, Kuender D Yang ${ }^{4}$, Chih-Hsing Hung ${ }^{5}$, Ya-Ju Yeh ${ }^{1}$, Chia-Ying Lee ${ }^{6}$ and \\ Ching-Yuang $\operatorname{Lin}^{6,7}$
}

Defective recruitment of regulatory T cells (Treg) function to the airway is important in the pathogenesis of allergic asthma. Complement regulatory protein (CD46) is a newly defined costimulatory molecule for Treg activation, which together with IL-10/granzyme B production may aid in suppressing asthmatic inflammation. This study examines chemotaxis and adhesion molecule expression on CD3/CD46-activated CD4 ${ }^{+} \mathrm{T}$ cells (Tregs) from patients with and without asthma to suppress mite allergen-induced respiratory epithelial cells inflammation and to elucidate the mechanism of CD46-mediated Treg activation. Diminished IL-10/granzyme B and CCR4 expression from CD3/CD46-activated Tregs appeared in asthmatic subjects. CD3/CD46-activated Tregs from asthma patients co-cultured with BEAS-2B cells suppressed Dermatophagoides pteronyssinus 2 induced nuclear factor- $\kappa \mathrm{B} / \mathrm{p} 65$ by cell contact inhibition. Decreased interaction of CD3/CD46-mediated Tregs and BEAS-2B cells from asthmatics was associated with downregulated phosphorylation of protein kinase B (AKT) expression. Results provide the first evidence that decreased interaction between CD46-mediated Tregs and lung epithelial cells with less IL-10/granzyme B production may cause airway inflammation in allergic asthma.

Laboratory Investigation (2012) 92, 1260-1269; doi:10.1038/labinvest.2012.86; published online 2 July 2012

KEYWORDS: adhesion; CD46; regulatory T cell

Loss of regulatory $\mathrm{T}$ (Treg) cells function appears critical to human allergic asthma pathogenesis. ${ }^{1}$ Tolerance to environmental allergens encountered on respiratory mucosal surfaces could be mediated by the development of Treg cells to suppress airway inflammation. ${ }^{1-3}$ Attention has focused on defects of natural occurring $\mathrm{CD} 4{ }^{+} \mathrm{CD} 25^{+}$Treg cells that regulate inflammatory response in asthmatic. ${ }^{4,5}$ Adaptive regulatory $\mathrm{T}$ ( $\operatorname{Tr} 1)$ cells secreting immunosuppressive cytokines may have a key role in maintaining immune tolerance to allergen in asthma. ${ }^{6,7}$

For recruiting allergen-specific $\mathrm{T}$ cells to the lungs, the expression of specific adhesion proteins and chemokine receptors is vital. ${ }^{8}$ Evidence from pediatric asthmatic subjects show that $\mathrm{CD}^{+}{ }^{+} \mathrm{CD} 25^{\mathrm{hi}}+$ Treg cells decrease in bronchoalveolar lavage fluid and fail to inhibit pulmonary TH2 responses, suggesting functional defective recruitment to the site of airway inflammation. ${ }^{9}$ Still, little is known about migration and retention mechanisms of Tregs and inducible $\operatorname{Tr} 1$ to airway where they maintain suppressive effectiveness in asthma. ${ }^{10}$

Studies reveal the complement system is activated locally and systemically to amplify inflammatory response in allergic asthmatics. ${ }^{11}$ Complement regulatory protein CD46, widely expressed in human leukocytes, epithelial cells and fibroblasts, is upregulated on certain activated leukocytes subsets to protect cells from autologous complement-mediated lysis at inflammatory sites. ${ }^{12-16}$ The mechanism for CD46 modulation of regulating $\mathrm{T}$ cells is addressed as (i) induction of T-cell proliferation, (ii) induction of $\operatorname{Tr} 1$ differentiation; and (iii) competition effect of IL-2 on the Th1/Tr1 balance. Cross-linking of CD46 during TCR activation leads to strong $\mathrm{CD} 4^{+}$T-cell proliferation and synthesis of large amounts of

\footnotetext{
${ }^{1}$ Department of Pediatrics, Changhua Christian Hospital, Changhua, Taiwan; ${ }^{2}$ School of Medicine, Chung Shan Medical University, Taichung, Taiwan; ${ }^{3}$ Department of Pediatrics, Taipei Veterans General Hospital, Institute of Clinical Medicine, National Yang-Ming University, Taipei, Taiwan; ${ }^{4}$ Department of Medical Research, Show Chwan Memorial Hospital, Chang Bing, Taiwan; ${ }^{5}$ Department of Pediatrics, Kaohsiung Medical University Hospital, Kaohsiung Medical University, Kaohsiung, Taiwan; ${ }^{6}$ Clinical Immunological Center, China Medical University Hospital, Taichung, Taiwan and ${ }^{7}$ Division of Pediatric Nephrology, Clinical Immunological Center, College of Medicine, China Medical University Hospital, Taichung, Taiwan

Correspondence: Professor C-Y Lin, MD, PhD, Division of Pediatric Nephrology, Clinical Immunological Center, College of Medicine, China Medical University Hospital, No.2, Yuh-Der Road, Taichung 40402, Taiwan.
}

E-mail: cylin@mail.cmuh.org.tw

Received 20 September 2011; revised 12 March 2012; accepted 6 April 2012 
IL-10 and granzyme B, similar to inducible $\operatorname{Tr} 1$ cells. ${ }^{17-21}$ CD46-costimulated human T cells differentiate toward a Th1 response with secreting IFN- $\gamma$, IL-10, granzyme B and compete for IL-2 as a growth factor may have a role in immune tolerance against allergic inflammation. ${ }^{22-24}$ Defective CD46costimulation Treg regulating immune responses correlates with autoimmune disease in multiple sclerosis. ${ }^{25-27} \mathrm{Xu}$ et al first demonstrated CD46-costimulated T cells acquiring a $\operatorname{Tr} 1$ phenotype with IL-10 production as impaired in a small group of asthma patients. ${ }^{28}$ We hypothesize mite-induced bronchial epithelial inflammation as deficiency in chemokine receptor expression by CD3/CD46-induced $\mathrm{CD}^{+}{ }^{+} \mathrm{T}$ cells (Tregs), leading to failed recruitment and reduced suppression at sites of allergic inflammation.

This study performed quantitative and functional analysis of CD3/CD46-activated Tregs in asthma patients to suppress recombinant $D$. pteronyssinus 2 (Der $\mathrm{p} 2$ )-induced bronchial epithelial BEAS-2B cells inflammation with nuclear factor $(\mathrm{NF})-\kappa \mathrm{B}$. We examined migratory potential of CD3/CD46activated Tregs, including expression of chemokine receptors. This study evaluated adhesion ability between CD3/CD46induced Treg and Der p 2 preactivated BEAS-2B cells, specifically with intracellular adhesion molecule-1 (ICAM-1) and chemokine intracellular signaling pathway, including protein kinase B (AKT) phosphorylation. Such research can elucidate CD3/CD46-activated Treg recruitment mechanisms, both in suppressing airway inflammation and in novel immunotherapeutic asthma treatment.

\section{MATERIALS AND METHODS Subjects}

A total of 60 mild intermittent to moderately persistent asthmatic children ( 28 boys and 32 girls; mean age $13.7 \pm 3.8$ years) with sensitivity to house dust mites (Der $p$ ), demonstrated by positive skin prick test (mean grade $3.3 \pm 0.7$ ) and IgE-specific test (mean $73.2 \pm 24.5 \mathrm{KU} / \mathrm{L}$ ) using the CAP system (Pharmacia Diagnostics, Uppsala, Sweden), were enrolled in this study. Definition of asthma was based on GINA guideline. Another 31 boys and 29 girls (mean age $13.2 \pm 4.5$ years) with normal serum IgE levels and negative for skin prick tests were recruited as healthy controls. The hospital's institutional review board approved the study, and parents of all subjects provided written informed consent.

\section{Antibody and Reagents}

Recombinant Der p 2 (Indoor Biotechnologies, Cardiff, UK) served as allergen. Nuclear factor $-\kappa \mathrm{B}(\mathrm{NF}-\kappa \mathrm{B}) / \mathrm{p} 65$, antiphopspho-AKT, $\beta$-actin was obtained for western blot analysis (Abcam, Cambridge, UK) Anti-human CD4, CD46, CD8, CCR4, CCR5, CCR7, CCR8, ICAM-1, pan Cytokeratin, granzyme $\mathrm{B}$, IFN- $\gamma$, IL-10 mAbs and isotype-matched mAbs conjugated with FITC, PE and PC5 and neutralizing anti-IL$10 \mathrm{mAb}$, were obtained from BD Biosciences (San Jose, CA) and Abcam.

\section{Tissue Sample, Cell Isolation and Cell Culture}

Bronchial mucosal specimens were taken by bronchoscopic biopsies according to the British Thoracic Society guidelines and lymphocytes were isolated directly after surgery for confocal immunofluorescence. Peripheral mononuclear cells (PBMCs) were isolated by Ficoll-paque gradient centrifugation (Pharmacia, Uppsala, Sweden). $\mathrm{CD}^{+} \mathrm{T}$ cells were purified from PBMCs, using microbeads according to manufacturer's protocol (BD Biosciences). Purity of CD4 ${ }^{+}$T-cell population analyzed by flow cytometry was $\geq 95 \%$. A total of $1 \times 10^{6} \mathrm{CD}^{+} \mathrm{T}$ cells were cultured with IL-2 $(10 \mu / \mathrm{ml})$, anti-human $\mathrm{CD} 3 \mathrm{mAb}(2 \mu \mathrm{g} / \mathrm{ml})$ with anti-human CD28 $\mathrm{mAb}(5 \mu \mathrm{g} / \mathrm{ml})$ or anti-human CD46 mAb $(5 \mu \mathrm{g} / \mathrm{ml})(\mathrm{BD}$ Biosciences) for 5 days. Confluent monolayer BEAS-2B cells (human bronchial epithelial cell line, American Type culture Collection, Rockville, MD) were cultured with or without CD3/CD46-activated CD4 ${ }^{+}$T cells in RPMI-1640 medium containing $10 \%$ fetal bovine serum (Bio-Whittaker, Walkersille, MD).

\section{Flow Cytometry and Cell Proliferation Assay}

PBMCs were fixed and stained for fluorescein-conjugated mAbs with isotype, CD46, CD4 and CD8. Chemokine receptors with CCR4, CCR5, CCR7 and CCR8, as well as intracellular IL-10 and IFN- $\gamma$ cytokines staining of CD3/CD46-activated $\mathrm{CD}^{+}{ }^{+} \mathrm{T}$ cells were determined by flow cytometry (FC500, Beckman Coulter, Fullerton, CA). To evaluate CD3/CD46activated $\mathrm{CD} 4{ }^{+} \mathrm{T}$ proliferation, $\mathrm{CD} 4^{+} \mathrm{T}$ cells were labeled with $5 \mu \mathrm{M}$ CFSE (Invitrogen, Carlsbad, CA) for $15 \mathrm{~min}$ at $37^{\circ} \mathrm{C}$. Cells were washed twice and stimulated with IL-2, anti-CD3 $\mathrm{mAb}$ and anti-CD46 mAb for 5 days, as previously described. At the end of culture, $\mathrm{CD} 4{ }^{+} \mathrm{T}$ cells proliferation was rated by CFSE fluorescence with flow cytometry.

\section{Confocal Immunofluorescence}

CD3/CD46-stimulated CD4 ${ }^{+} \mathrm{T}$ cells from asthmatic and nonatopic subjects were incubated with a anti-CD46 antibody (Genetex, Irvine, CA), anti-CD4 antibody, antigranzyme B antibody (Abcam), followed by AlexaFluor 488-conjugated anti-rabbit (Invitrogen), or AlexaFluor 546-conjugated antimouse (Invitrogen) secondary antibody, according to manufacturer's instructions. Confocal immunofluorescence pictures were taken by Leica TCS SP2 confocal spectral microscope.

\section{Enzyme-Linked Immunosorbent Assay (ELISA)}

IFN- $\gamma$ and IL-10 concentrations of cell supernatants were determined by commercially available ELISA-based assay systems (R\&D Systems, London, UK). Assay was performed as per manufacturer's protocol.

\section{Real-Time Quantitative Reverse TranscriptionPCR (RT-PCR) Analysis}

Cyt1 and Cyt2 transcription factors mRNA were analyzed by SYBR Green PCR Kit (Applied Biosystems, California). Specific primers were used: Cyt1: sense 5'-CTAACTGATGA 
GACCCACAGAGAAGT- $3^{\prime}$, antisense $5^{\prime}$-TCAGCTCCACCAT CTGCTTTC-3'; Cyt2, sense 5'-GAAGAAAGGGAAAGCAG ATGGT- $3^{\prime}$, antisense $5^{\prime}$-CCTCTCTGCTCTGCTGGAGTG-3' . $\beta$-actin: sense $5^{\prime}$-TTCTGTGGCATCACGAAACT- $3^{\prime}$ antisense $5^{\prime}$-GAAGCATTTGCGGTGGACGAT- $3^{\prime}$, as previously published. ${ }^{25}$ Cyt1 and Cyt2 mRNA expression was calculated as fold change using formula $2^{\Delta C \mathrm{t}} \Delta C_{\mathrm{T}}=\Delta C_{\mathrm{T}}($ control $)-\Delta C_{\mathrm{T}}$ (target), in which $C_{\mathrm{T}}$ indicates cycle threshold.

\section{Transepithelial Migration and Cell Adhesion Assay}

To determine whether CD3/CD46-activated CD4 ${ }^{+}$Treg cells migrate across BEAS-2B cells via Der $\mathrm{p} 2$ stimulation, time course of in vitro transepithelial migration model was used. ${ }^{29}$ Lower and upper chambers were separated by a culture insert with polycarbonate membrane (5-mm pore size), using a 24-well Micro Chemotaxis Transwell (Corning Costar, Cambridge, MA). Confluent BEAS-2B cells were cultured and seeded onto the bottom side of culture insert, then preincubated with Der p $2(10 \mu \mathrm{g} / \mathrm{ml})$ for $2 \mathrm{~h}$. CD3/CD46-activated $\mathrm{CD}^{+} \mathrm{T}$ lymphocytes at $1 \times 10^{6}$ cells $/ \mathrm{ml}$ loaded onto the upper chamber were left to transmigrate at $37^{\circ} \mathrm{C}$ in humidified atmosphere with $5 \% \mathrm{CO} 2$. After incubation for 2 , 6,12 and $18 \mathrm{~h}$, number of migrated $\mathrm{CD} 3 / \mathrm{CD} 46$-activated $\mathrm{CD} 4{ }^{+} \mathrm{T}$ lymphocytes in the lower compartment was calculated by counting cells under a light microscope. Migration percentage was derived from 30 paired separate experiments.

To analyze further physical interaction of CD3/CD46induced $\mathrm{CD} 4{ }^{+}$Tregs with BEAS-2B cells, in vitro imaging assay was set up by CFSE labeled with $1 \times 10^{5} \mathrm{CD} 3 / \mathrm{CD} 46-$ activated $\mathrm{CD} 4^{+}$T cells cultured with $1 \times 10^{5}$ BEAS-2B cells in the presence of Der p $2(10 \mu \mathrm{g} / \mathrm{ml})$. Serial images were taken at intervals of $10 \mathrm{~min}$ for $2 \mathrm{~h}$ after culture by time-lapse photography.

\section{Electrophoretic Mobility Shift Assay (EMSA) of NF- $\kappa$ B Activity}

To examine suppression activity by $\mathrm{CD} 3 / \mathrm{CD} 46$-stimulated Treg cells, BEAS-2B cells were pretreated with recombinant Der p $2(10 \mu \mathrm{g} / \mathrm{ml})$ for $12 \mathrm{~h}$ and confluent BEAS-2B cells $\left(5 \times 10^{5}\right.$ per well) cultured with $\mathrm{CD} 3 / \mathrm{CD} 46$-activated $\mathrm{CD} 4{ }^{+}$ $\mathrm{T}$ cells $\left(1 \times 10^{5}\right.$ per well $)$ in a six-well plate for $2 \mathrm{~h}$ more. CD3/CD46-stimulated Tregs were separated from adherent BEAS-2B by washing with PBS without Treg and epithelial cell purity was examined by light microscope before analyzing for ICAM expression. We also performed double staining with BEAS-2B epithelium marker (pan Cytokeratin) and ICAM-1 to acquire the results. Nuclear proteins from BEAS-2B cells were extracted with Nuclear Extraction Kit (Panomics, Fremont, CA). A biotin end-labeled NF- $\kappa$ B probe $\left(5^{\prime}\right.$-AGTTGAGGGACTTTCCCAGGC- $\left.3^{\prime}\right)$ was used and NF- $\kappa$ B protein-DNA binding complex was determined using EMSA kit (Panomics), according to manufacturers' instruction.

\section{Western Blot Analysis}

Protein levels of NF- $\kappa \mathrm{B}$, phospho-AKT were determined by western blot analysis. Equal amounts of proteins in each study groups were ascertained by Bio-Rad protein assay kit (Bio-Rad, Hercules, CA). Cellular proteins were resolved by $10 \%$ SDS-polyacrylamide gel. After electrophoresis, protein levels of nuclear NF- $\kappa \mathrm{B} / \mathrm{p} 65$, phosphor-AKT by western blot as previously described. ${ }^{5}$

\section{Statistical Analysis}

All data were presented as mean \pm s.d. Comparisons between asthmatic and healthy control groups were analyzed by Mann-Whitney $U$-test. Data sets in each study group were compared by Kruskal-Wallis test, followed by the Duncan test, $P<0.05$ considered statistically significant.

\section{RESULTS \\ Surface CD46 Expression on CD4 ${ }^{+}$Cells Less in Mite- Sensitive Asthmatics}

Confocal microscopic analysis of human bronchial mucosa biopsies revealed $\mathrm{CD} 4{ }^{+} \mathrm{CD} 46^{+} \mathrm{T}$ cells decreasing in mite-sensitive asthmatics $(n=3)$ vs nonatopic subjects $(n=3)$ with essentially identical results (Figure 1a). To test differential CD46 molecule expression on T lymphocyte subsets by mite allergen stimulation between asthmatic patients and healthy subjects, PBMCs were stimulated with Der p 2, then analyzed by flow cytometry for CD46 surface expression of $\mathrm{CD} 4^{+}$and $\mathrm{CD}{ }^{+} \mathrm{T}$ cells simultaneously. Number of $\mathrm{CD} 4{ }^{+} \mathrm{CD} 46^{+}$cells decreased in asthmatics compared with healthy subjects $(P<0.05)$ (Table 1).

\section{Lower Intracellular IL-10 Level of CD3/CD46-Activated Tregs in Asthmatics}

To study CD3/CD46 cross-linkage on human $\mathrm{CD}^{+} \mathrm{T}$ lymphocyte proliferation, purified $\mathrm{CD} 4^{+} \mathrm{T}$ cells was labeled by CFSE and were stimulated with anti-CD3/CD46 or anti$\mathrm{CD} 3 / \mathrm{CD} 28$ in the presence of IL-2. Proliferation of CD3/ CD46-activated $\mathrm{T}$ cells did not significantly differ between healthy donors and asthmatics (Figure 1b). Experiments were performed to examine IL-10 expression of CD3/CD46-activated $\mathrm{CD} 4{ }^{+} \mathrm{T}$ cells (Figure 1d). The $\mathrm{CD} 3 / \mathrm{CD} 46$-activated $\mathrm{CD}^{+}{ }^{+} \mathrm{T}$ cells had significantly higher IL-10 expression $(13.2 \pm 4.5 \%)$ compared with CD3-activated $\mathrm{CD}^{+}{ }^{+} \mathrm{T}$ cells $(4.4 \pm 3.2 \%)$ in healthy controls $(P<0.05)$ (Figure 1e). IL-10 expression decreased $(13.2 \pm 4.5 \%$ vs $3.8 \pm 3.6 \%, P<0.05)$ on $\mathrm{CD} 4{ }^{+} \mathrm{T}$ cells after CD46 costimulation in asthmatics compared with normal subjects (Figure 1e). Upon CD28 costimulation of $\mathrm{CD}^{+}{ }^{+} \mathrm{T}$ cells, IL-10 expression decreased in asthmatic compared with normal subjects, albeit not significantly different $(12.7 \pm 4.9 \%$ vs $15.9 \pm 5.6 \%, P>0.05)$ (Figure 1e). CD3/CD46-activated $\mathrm{CD} 4{ }^{+} \mathrm{T}$ cells showed significantly higher IFN- $\gamma$ expression in healthy controls than in asthmatics (Figure 1c). Experiments were performed 
a

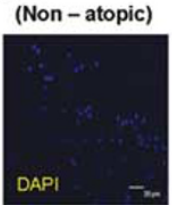

(Asthma)
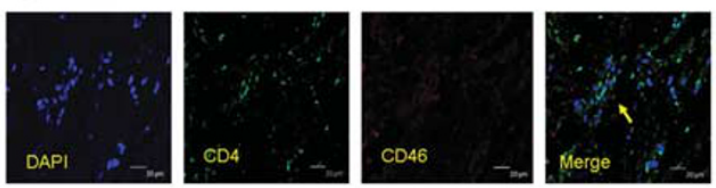

C Non-atopic group
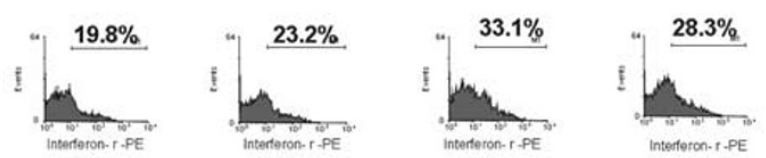

Non-Active

Anti-CD3

Asthmatic group
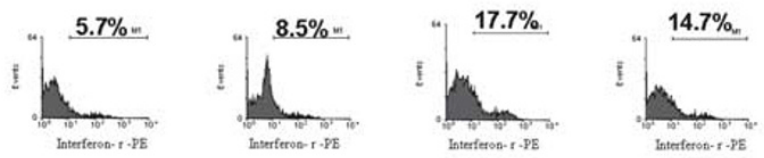

e
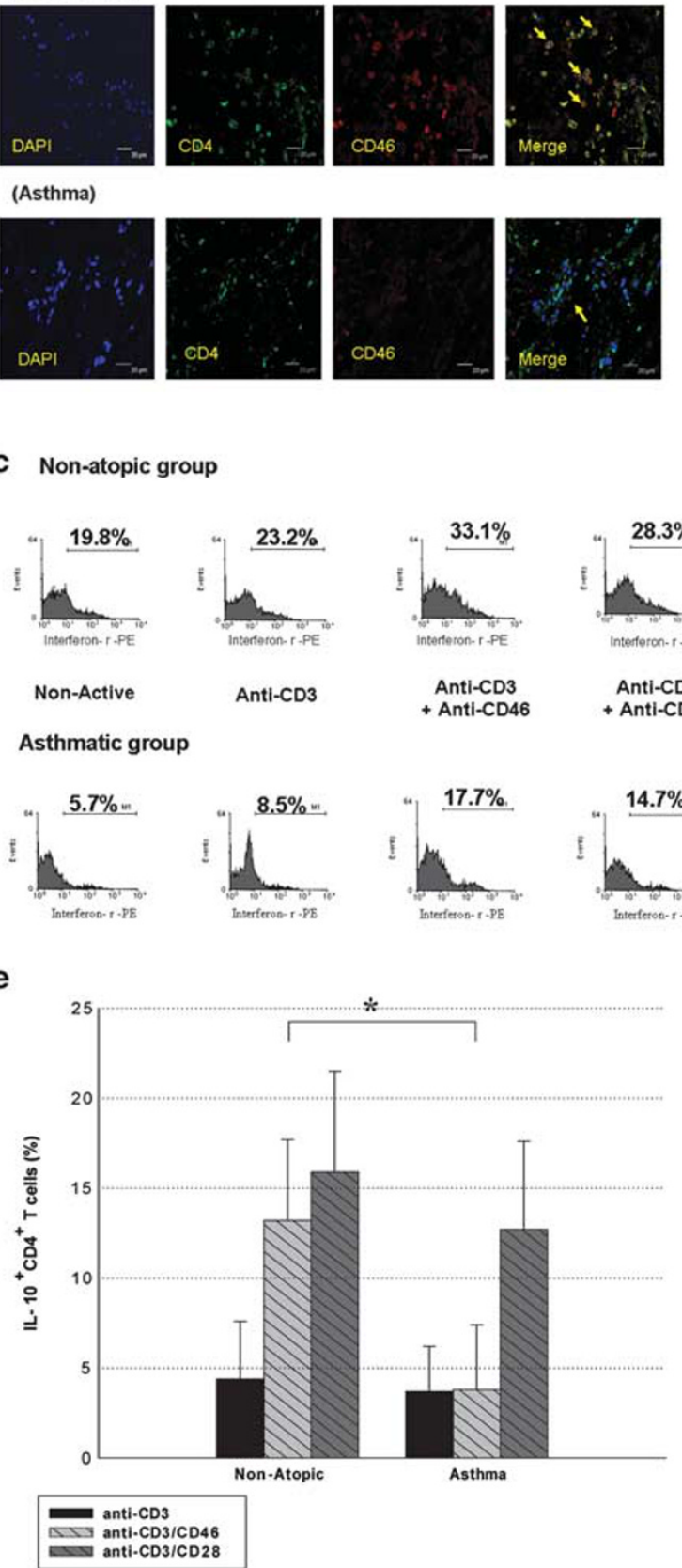

b

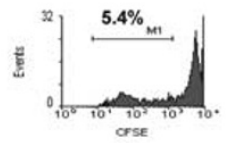

orse

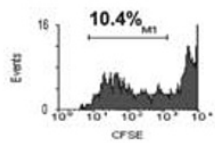

crse

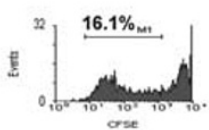

d Non-atopic group
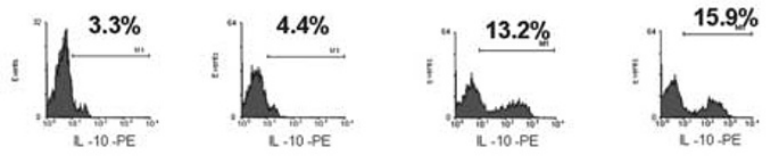

Non-Active

Anti-CD3

Anti-CD3 + Anti-CD46

Anti-CD3

Asthmatic group
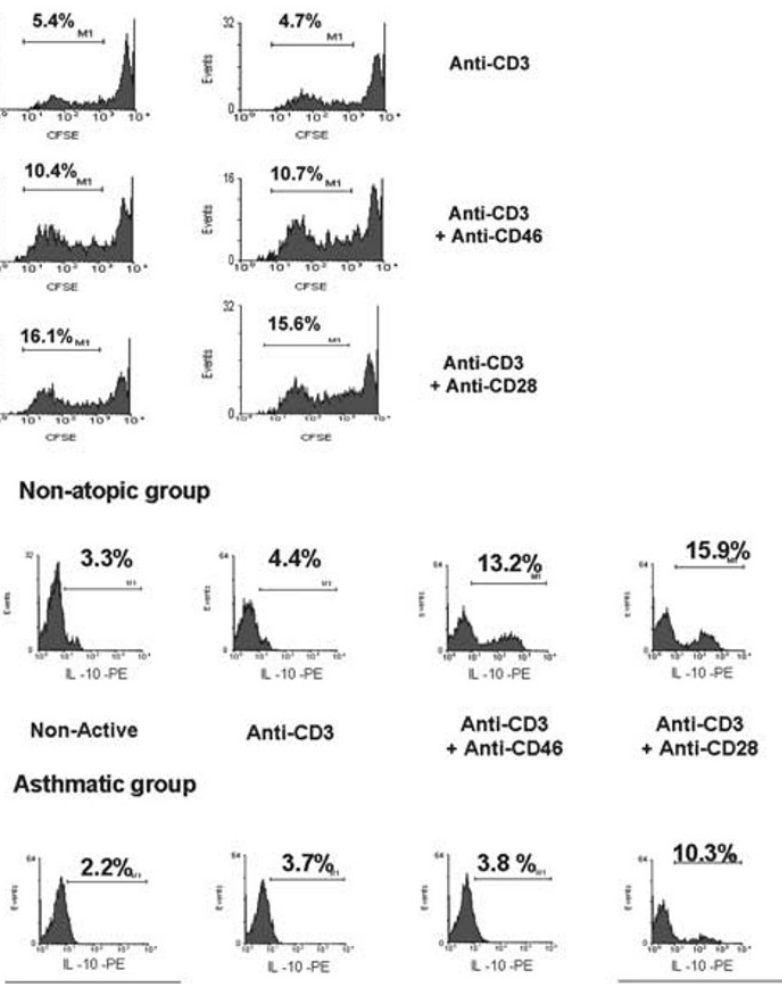

f $C D 4+T$ cells (IL-2 only)
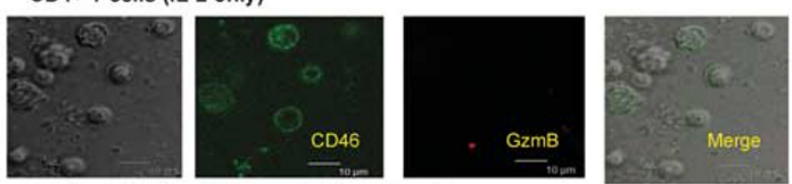

CD3/CD46 induced Treg cells (Non-atopic)
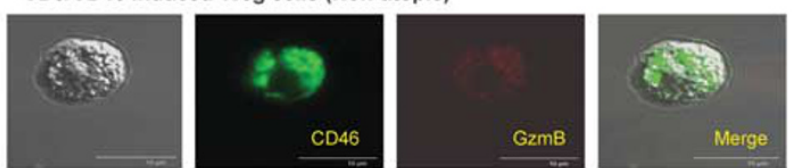

CD3/CD46 induced Treg cells (Asthma)
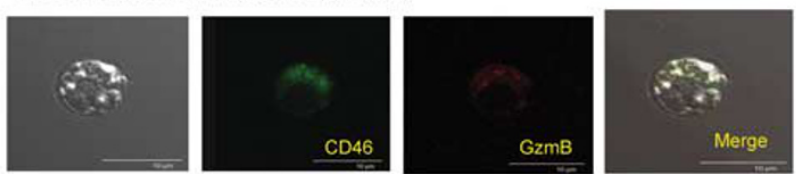

Figure $1 \mathrm{CD}^{+}{ }^{+} \mathrm{CD} 46^{+} \mathrm{T}$ cells decreased in bronchial tissue from mite-sensitive asthma patients. (a) Confocal microscopic analysis of bronchial mucosa biopsies between mite-sensitive asthma $(n=3)$ vs nonatopic subjects $(n=3)$. Bronchial mucosa biopsy stained for CD4, CD46 and $4^{\prime}, 6$-diamidino-2phenylindole (nuclear stain). Yellow arrows indicate CD4 ${ }^{+} \mathrm{CD} 46^{+}$T cells. (b) CFSE-labeled purified CD4 ${ }^{+}$T cells from normal $(n=30)$ and asthmatic subjects $(n=30)$ were pretreated with IL-2, anti-CD3 anti-CD28 or anti-CD46 mAb for 5 days and analyzed by flow cytometry. Intracellular interferon- $\gamma(\mathbf{c})$ and IL-10 (d) levels in purified $\mathrm{CD}^{+}{ }^{+} \mathrm{T}$ cells not activated or activated for 5 days with various combination of mAb to anti-CD3, anti-CD28 or anti-CD46 mAb plus IL-2 followed by PMA/ionomycin for an additional $5 \mathrm{~h}$ in the presence of Golgistop and stained for the cytokines indicated. (e) IL-10 production by CD3/CD46activated $\mathrm{CD}^{+}{ }^{+} \mathrm{T}$ cells decreased in 30 paired asthmatic subjects ( ${ }^{*}$ mean $\left.P<0.05\right)$. (f) Co-expression of CD46 and granzyme B in CD3/CD46-activated CD4 ${ }^{+}$ T cells among normal $(n=30)$ and asthmatic subjects $(n=30)$ by confocal Immunofluorescence showed essentially identical results.

on 10 paired samples with essentially identical results. When cytokine secretion was quantified by ELISA, a striking defect with CD46-mediated IL-10 and IFN- $\gamma$ production was observed in asthmatics when compared with controls (Table 2).

\section{Decreased CD46 and Granzyme B Co-Expression on CD3/CD46-Activated Tregs in Asthma Patients by Confocal Immunofluorescence}

Double immunoflurorescent staining was used for CD46 and granzyme $\mathrm{B}$ expression in $\mathrm{CD} 3 / \mathrm{CD} 46$-activated $\mathrm{CD} 4{ }^{+} \mathrm{T}$ cells 
Table 1 CD46 expression on T-lymphocytes subsets (\%) in asthmatic and nonatopic subjects after Der $p 2$ stimulation

Asthma

Control

$$
\begin{aligned}
& \text { CD4 } 4^{+} \text {cells } \\
& \text { Day } 0(-) \\
& \text { Day } 5(-) \\
& \text { Day } 5(+ \text { Der p 2) }
\end{aligned}
$$$$
41.9 \pm 8.2
$$$$
45.8 \pm 7.5
$$

$39.4 \pm 8.5$

$34.6 \pm 7.9^{*}$

$43.7 \pm 6.2$

$42.5 \pm 7.4$

$$
\begin{aligned}
& \text { CD } 8^{+} T \text { cells } \\
& \text { Day } 0(-) \\
& \text { Day } 5(-) \\
& \text { Day } 5(+ \text { Der p 2) }
\end{aligned}
$$

$33.8 \pm 5.8$

$34.8 \pm 5.9$

$29.3 \pm 6.1$

$29.4 \pm 7.6$

$27.1 \pm 6.6$

$26.1 \pm 5.8$

PBMCs after Der p $2(10 \mu \mathrm{g} / \mathrm{ml})$ for 5 days was observed in asthmatic patients $(n=60)$ vs controls $(n=60)$.

${ }^{*} P<0.05$ intergroup comparison.

Table 2 Effect of costimulatory molecules on cytokine production of $\mathrm{CD4}^{+} \mathrm{T}$ cells between asthmatic and nonatopic subjects

Anti-CD3 Anti-CD3+anti-CD28 Anti-CD3+anti-CD46

$\begin{array}{cccc}\text { IL-10 }(\mathrm{pg} / \mathrm{ml}) & & & \\ \text { Asthma } & 90.3 \pm 9.5 & 106.7 \pm 7.5 & 94.8 \pm 5.7 \\ \text { Control } & 95.1 \pm 7.9 & 174.5 \pm 19.2^{*} & 156.5 \pm 8.3^{*}\end{array}$

IFN- $\gamma(\mathrm{pg} / \mathrm{ml})$

$\begin{array}{lrrr}\text { Asthma } & 40.9 \pm 4.9 & 59.1 \pm 8.5 & 79.7 \pm 9.4 \\ \text { Control } & 43.1 \pm 6.5 & 113.5 \pm 8.5^{*} & 181.5 \pm 6.0^{*}\end{array}$

${ }^{*} P<0.05$ comparison between groups.

between asthmatic and nonatopic subjects. Decreased CD46 expression associated with diminished granzyme $\mathrm{B}$ in CD46activated $\mathrm{CD}^{+} \mathrm{T}$ cells in asthmatic patients $(P<0.05)$ (Figure 1f). Experiments were performed on 30 paired samples, with essentially identical results.

\section{Decreased Cyt1 mRNA and Increased Cyt2 mRNA in CD3/CD46-Activated Treg Cells from Asthmatic Patients} To explore mechanism whereby CD3/CD46-activated CD4 ${ }^{+}$ $\mathrm{T}$ cells loses IL-10 secretion in asthmatics, both cytoplasmic isoforms of CD46 were examined; Cyt1 inhibits inflammatory reaction, whereas Cyt2 augments inflammation correlating with decreased IL-10 production as proven by mouse model. ${ }^{12}$ Quantitative RT-PCR analysis of Cyt1 mRNA and Cyt2 mRNA in CD3/CD46-induced Tregs from asthmatics revealed decreased CD46-Cyt1 isoform mRNA (Figure 2a) and increased CD46-Cyt2 isoform mRNA (Figure 2b) compared with controls.
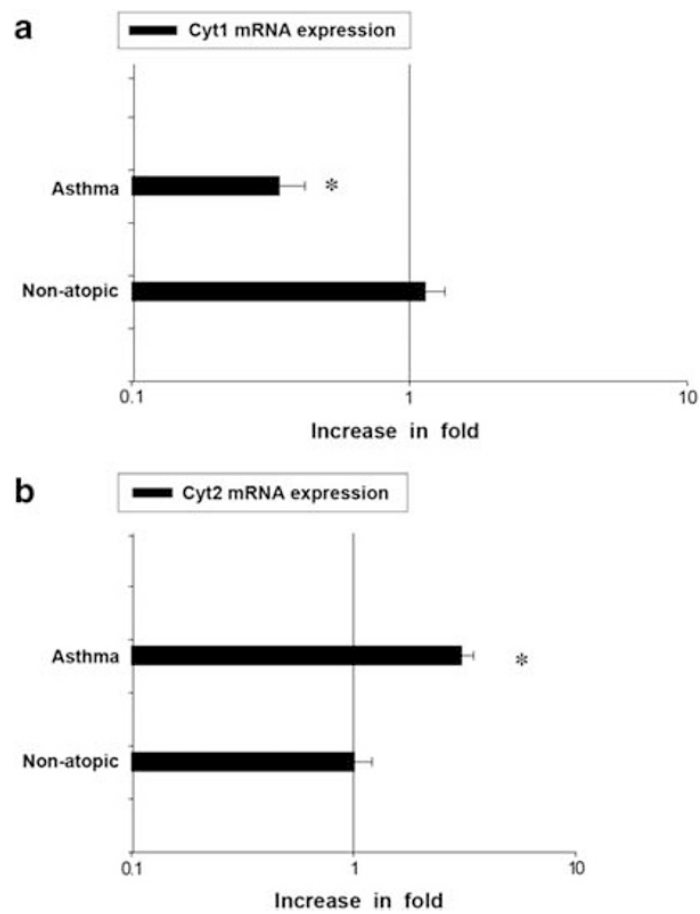

Figure 2 Quantitative RT-PCR analysis of Cyt1 mRNA and Cyt2 mRNA in $\mathrm{CD}^{+}{ }^{+} \mathrm{T}$ cells from patients by CD3/CD46 stimulation. Cyt1 mRNA decreased (a) with increased Cyt2 mRNA expression (b) in asthmatic subjects compared with controls. ${ }^{*}$ mean $P<0.05$.

Decreased Migration and Adhesion Between CD3/CD46Activated Tregs and BEAS-2B by Der $p 2$ Stimulation in Asthmatic Patients

To determine whether CD3/CD46-activated Tregs migrate across BEAS-2B cells under Der p 2 stimulation, a time course of migration capacity of CD3/CD46-activated CD4 ${ }^{+}$ $\mathrm{T}$ lymphocytes was examined by in vitro transepithelial migration system. Percentage of $\mathrm{CD} 3 / \mathrm{CD} 46$-activated $\mathrm{CD} 4^{+} \mathrm{T}$ cells migrating across BEAS-2B monolayer rose with apical prestimulation Der p 2 compared with those without stimulation (Figure 3a). Migration of $\mathrm{CD} 3 / \mathrm{CD} 46$-activated $\mathrm{CD}^{+} \mathrm{T}$ cells across prestimulated BEAS-2B epithelium decreased in asthmatic subjects. Figure 3a shows experiments on 30 paired samples and statistical data.

To analyze mode of physical interaction of CD3/CD46induced $\mathrm{CD} 4{ }^{+} \mathrm{T}$ cells with BEAS-2B cells, in vitro imaging assay was set up containing mixture of CFSE-labeled with $\mathrm{CD} 3 / \mathrm{CD} 46-$ induced $\mathrm{CD} 4^{+} \mathrm{T}$ and BEAS-2B cells in the presence of Der $\mathrm{p} 2$ 2. Images were taken at intervals of $10 \mathrm{~min}$ for $2 \mathrm{~h}$ after culture (Figure 3b). Tracing CD3/CD46-induced $\mathrm{CD}^{+} \mathrm{T}$ cells from nonatopic subjects $(n=10)$ revealed higher mobility than in asthmatics $(n=10)$ around BEAS-2B cells in an early phase of culture and representative data with essentially identical results (Figure 3b). Original films in cultured system between control (Supplementary Online Film 1) and asthmatics (Supplementary Online Film 2), served as Supplementary Material. 

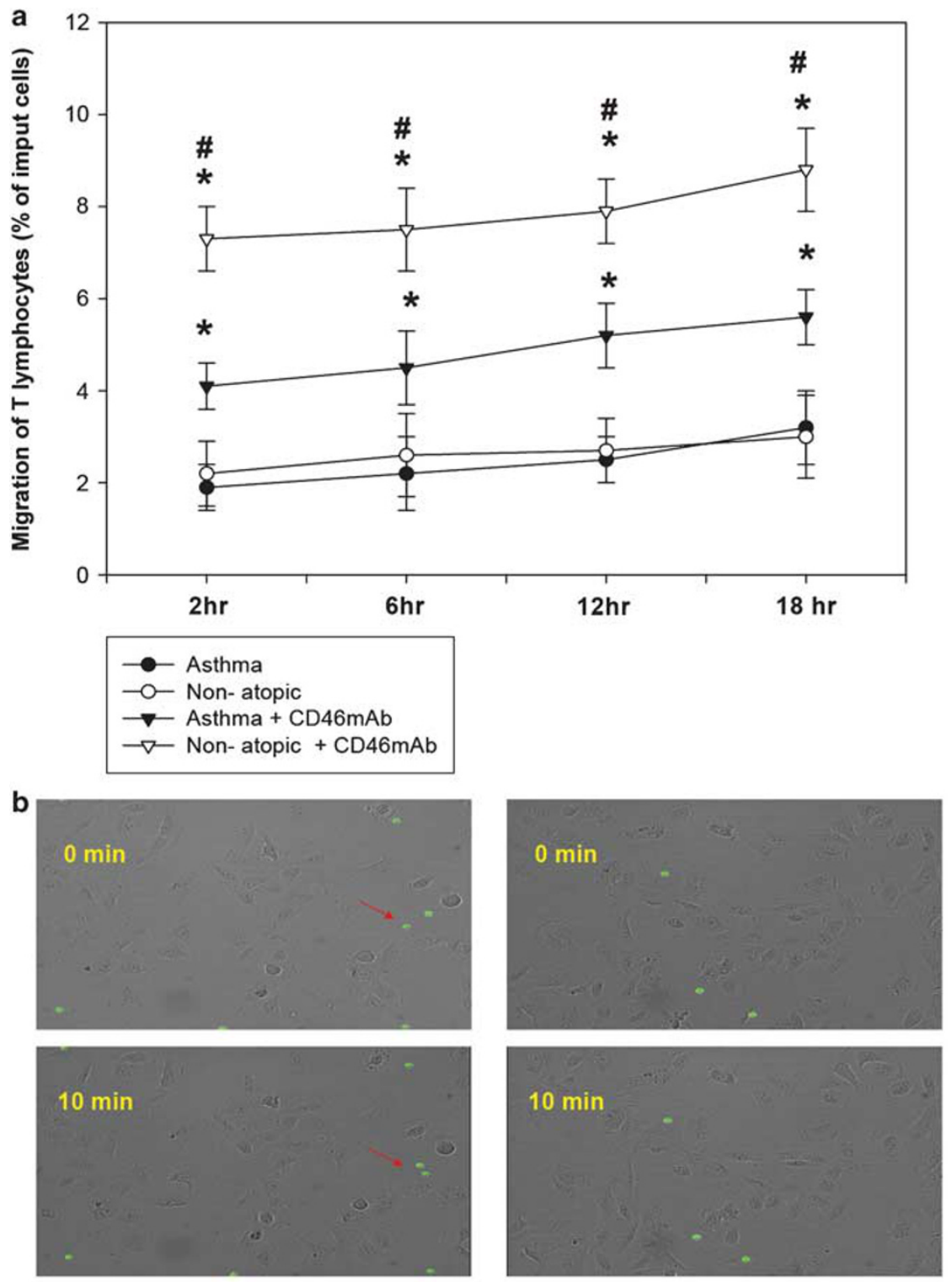

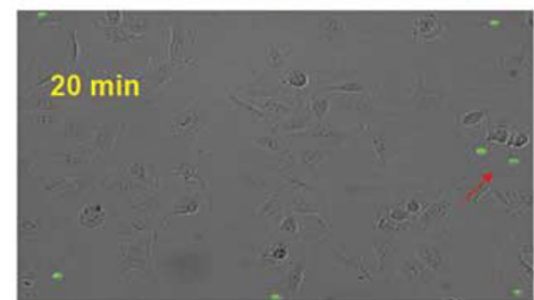

(Non-atopic)

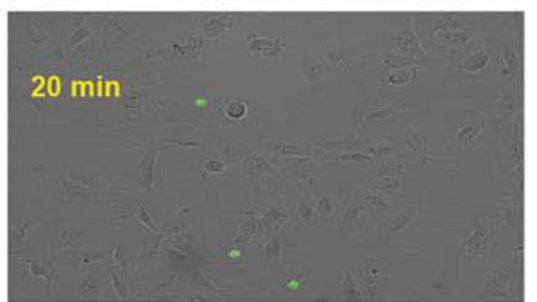

(Asthma)

Figure 3 Effect of Der $p 2$ on migration and adhesion between CD3/CD46-activated Treg and BEAS-2B epithelial cells. (a) Apical prestimulation of BEAS-2B monolayer with Der $\mathrm{p} 2$ increased migration of CD3/CD46-activated CD4 ${ }^{+}$T cells across BEAS-2B cells. ${ }^{\#} P<0.05$ between asthmatic and nonatopic subjects. ${ }^{\star} P<0.05$ after Der $\mathrm{p} 2$ stimulation. (b) High mobility of CD3/CD46-induced $C D 4{ }^{+} \mathrm{T}$ cells interacting with BEAS-2B epithelium in nonatopic subjects. A mixture of CFSE labeled with CD3/CD46-activated CD4 ${ }^{+}$T cells (arrow) and BEAS-2B at 1:1 ratio in the presence of Der $\mathrm{p} 2(10 \mu \mathrm{g} / \mathrm{ml})$. Images were taken at intervals of $10 \mathrm{~min}$ for $2 \mathrm{~h}$ after culture.

\section{CD3/CD46-Activated Tregs Inhibit Der p 2-Activated BEAS-2B Cells NF- $\kappa$ B by Cell Contact}

Recombinant house dust allergen Der $\mathrm{p} 2$ was shown to activate respiratory epithelial cells (BEAS-2B) inducing $\mathrm{NF} \kappa \mathrm{B}$ and pro- ducing inflammatory mediators. Suppression of NF- $\kappa$ B activity in Der $\mathrm{p}$ 2-preactivated BEAS-2B cells by CD3/CD46-activated $\mathrm{CD}^{+}{ }^{+} \mathrm{T}$ cells was studied. CD3/CD46-activated $\mathrm{CD} 4^{+} \mathrm{T}$ cells inhibited Der $\mathrm{p}-2$-induced NF- $\kappa \mathrm{B} / \mathrm{p} 65$ on BEAS- $2 \mathrm{~B}$ cells in a 
a

\begin{tabular}{|c|c|c|c|c|c|c|c|}
\hline BEAS-2B & $\begin{array}{c}\text { BEAS-28 } \\
\text { +Der p 2 }\end{array}$ & Asthma & Control & Asthma & Control & Asthma & Control \\
\hline & & + CD 46- & + CD 46- & + CD46- & + CD46- & + CD 46- & + +CD46- \\
& & Treg & Treg & Treg & Treg & Treg & Treg \\
& & $1: 0.01$ & $1: 0.01$ & $1: 0.1$ & $1: 0.1$ & $1: 1$ & $1: 1$ \\
\hline
\end{tabular}

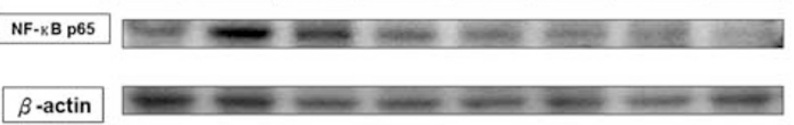

Ratio : Der p-2 activated BEAS-2B: CD3/CD46-induced CD4 Treg

b
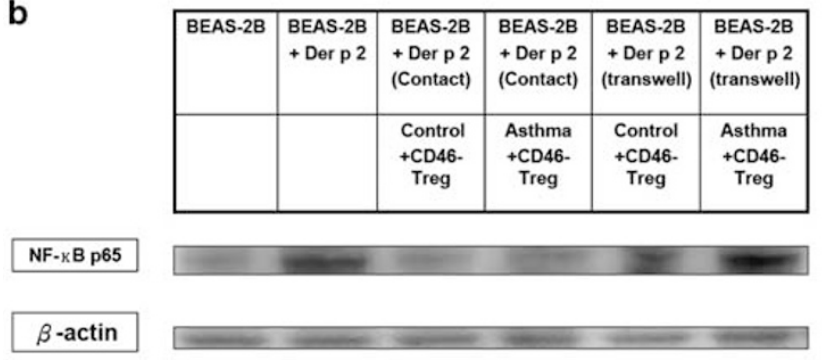

d

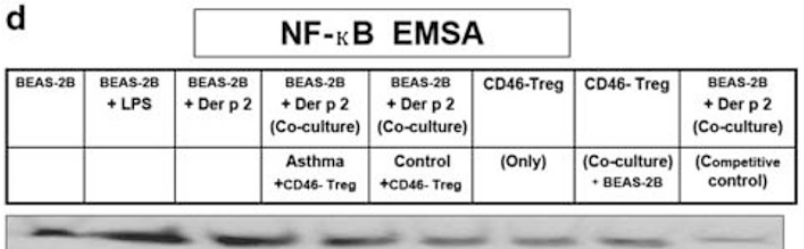

C

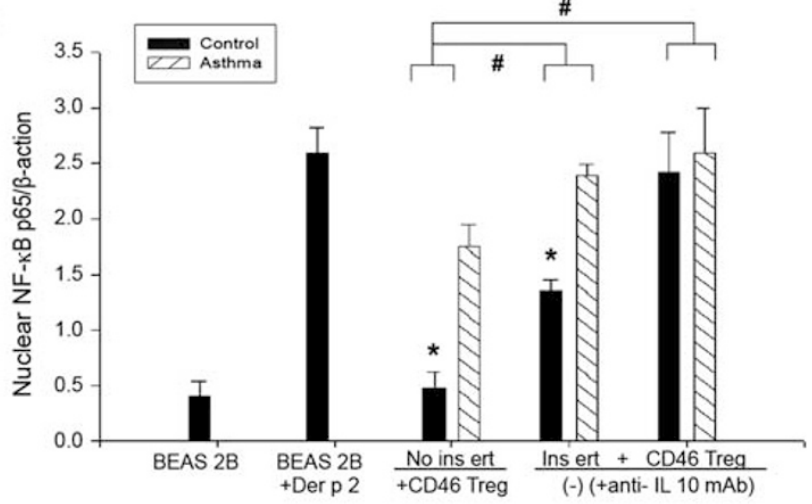

e

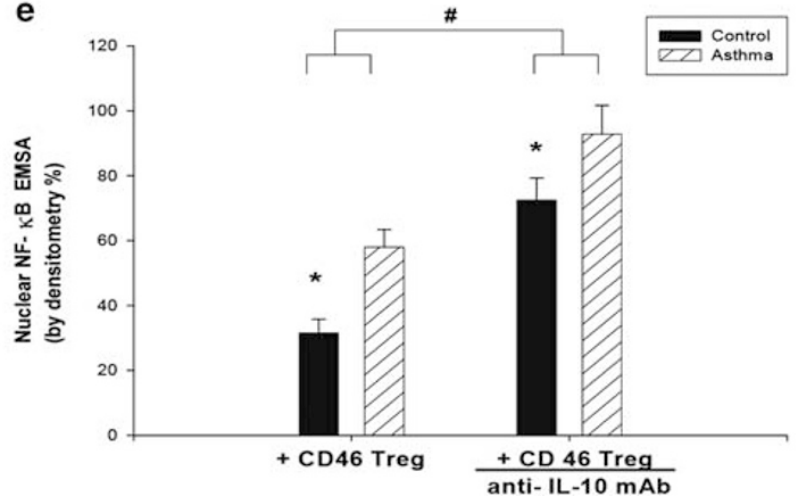

Figure 4 Inhibition of NF- $\kappa$ B activity in Der p 2-activated BEAS-2B cells when cultured with CD3/CD46-induced CD4 ${ }^{+} \mathrm{T}_{\text {cells. }}$ BEAS-2B cells were pretreated with Der p $2(10 \mu \mathrm{g} / \mathrm{ml})$ for $12 \mathrm{~h}$, confluent BEAS-2B cells $\left(5 \times 10^{5}\right.$ per well) cultured with CD3/CD46-activated CD4 ${ }^{+} \mathrm{T}$ cells $\left(1 \times 10^{5}\right.$ per well) in a six-well plate for another $2 \mathrm{~h}$. CD3/CD46-stimulated Treg cells were separated from adherent BEAS-2B by washing with PBS, nuclear proteins extracted from BEAS-2B cells and analyzed by (a) western blot and (d) EMSA for inhibition of NF- $\kappa$ B activity. (b) Transwell experiments were performed to detect $\mathrm{CD} 3 / \mathrm{CD} 46$-induced $\mathrm{CD} 4{ }^{+} \mathrm{T}$ inhibition with NF- $\kappa \mathrm{B}$ activity. (c) Statistical data of 30 paired samples (between asthmatic and nonatopic groups) and 6 paired samples following treatment with neutralizing anti-IL10 mAb. (e) Enhancement of NF- $\kappa$ B experiment from BEAS-2B cells co-cultured with $\mathrm{CD} 3 / \mathrm{CD} 46$-induced $\mathrm{CD}^{+}{ }^{+} \mathrm{T}$ following treatment with neutralizing anti-IL10 mAb. Three independent experiments produced essentially identical results. $\# P<0.05$ between asthmatic and nonatopic subjects. ${ }^{*} P<0.05$ after treatment with antineutralizing IL-10 mAb.

dose-dependent manner (Figure 4a). Transwell inset experiments (pore size $0.4 \mu \mathrm{M}$ ) also showed that $\mathrm{CD} 3 / \mathrm{CD} 46$-activated $\mathrm{CD} 4{ }^{+} \mathrm{T}$ cells inhibit Der p 2-induced NF- $\kappa \mathrm{B} / \mathrm{p} 65$ on BEAS-2B cells, chiefly by cell contact inhibition (Figure $4 \mathrm{~b}$ ). Figure $4 \mathrm{c}$ shows experimental data on 30 paired samples. Decreased CD3/CD46-activated Tregs inhibition of NF- $\kappa$ B activity in Der $\mathrm{p} 2$-activated BEAS-2B cells was confirmed by EMSA (Figure $4 \mathrm{~d}$ and e). To test CD3/CD46-activated Tregs suppression of Der p 2-induced inflammation via IL-10 secretion and neutralizing antibody against IL-10 was added to co-cultures. Enhanced NF- $\kappa$ B from BEAS-2B cells in co-cultures with CD3/CD46-induced $\mathrm{CD} 4{ }^{+} \mathrm{T}$ cells following treatment with neutralizing anti-IL10 mAb was noted $(P<0.05)$. Three independent experiments yielded virtually identical results (Figure 4e).

\section{Decreased CCR4 and AKT Phosphorylation in CD3/CD46- Induced Tregs from Asthmatic Patients}

Chemokine receptors and signaling cascade downstream in CD3/CD46-activated $\mathrm{CD}^{+}{ }^{+} \mathrm{T}$ cells was investigated. Specific expression of CCR4, CCR5, CCR7 and CCR8 on Tregs might allow migration towards inflammatory sites leading to inhibition of responding cells. Percentage and expression of CCR 4 on $\mathrm{CD} 3 / \mathrm{CD} 46$-activated $\mathrm{CD} 4^{+} \mathrm{T}$ cells declined significantly in asthmatics, compared with healthy controls (Figure $5 \mathrm{a}$ and $\mathrm{b}$ ).

Decreased adhesion between CD3/CD46-activated CD4 ${ }^{+}$ $\mathrm{T}$ cells and BEAS-2B cells were involved in the ICAM-1, and chemokine signaling pathway was explored. Co-culture of CD3/CD46-activated CD4 ${ }^{+}$T cells and BEAS-2B cells could significantly enhance cell surface expression of adhesion molecule ICAM-1 on BEAS-2B cells in the presence of Der p 2 (Figure 5c). Percentage of ICAM-1 on BEAS-2B cells when co-cultured with $\mathrm{CD} 3 / \mathrm{CD} 46$-activated $\mathrm{CD} 4{ }^{+} \mathrm{T}$ cells was greater in healthy controls than in asthmatics ( $41.5 \pm 6.7 \%$ vs $24.3 \pm 5.9 \%, P<0.05)$ (Figure 5 c).

AKT phosphorylation in CD46-activated $\mathrm{CD} 4{ }^{+} \mathrm{T}$ cells when co-cultured with BEAS-2B cells in the presence of Der p 2 was studied (Figure 5d). AKT phosphorylation (Figure 5e) declined in BEAS-2B while CD3/CD46-activated $\mathrm{CD} 4{ }^{+} \mathrm{T}$ cells appeared in asthmatics $v s$ controls; experimental data 30 paired samples are shown. 
a Non-atopic group

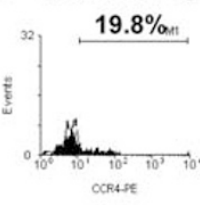

CCR4

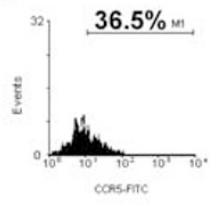

CCR5

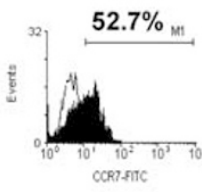

CCR7

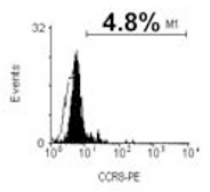

CCR8
Asthmatic group
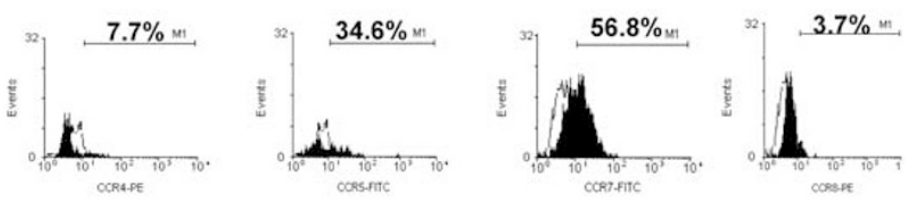

$3.7 \% m$

c
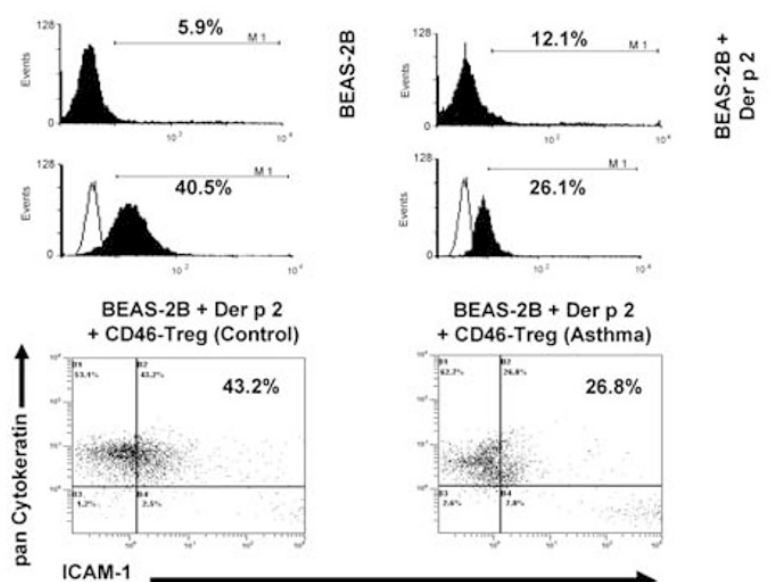

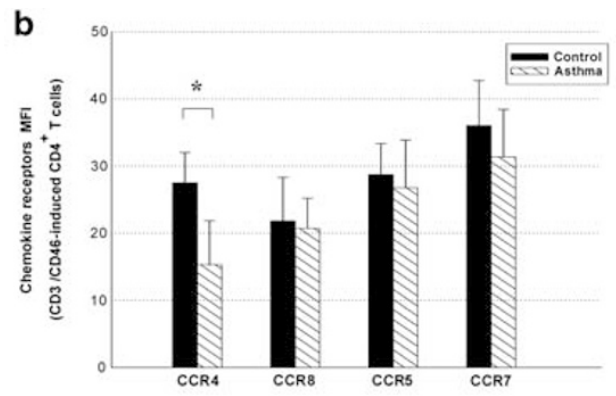

d
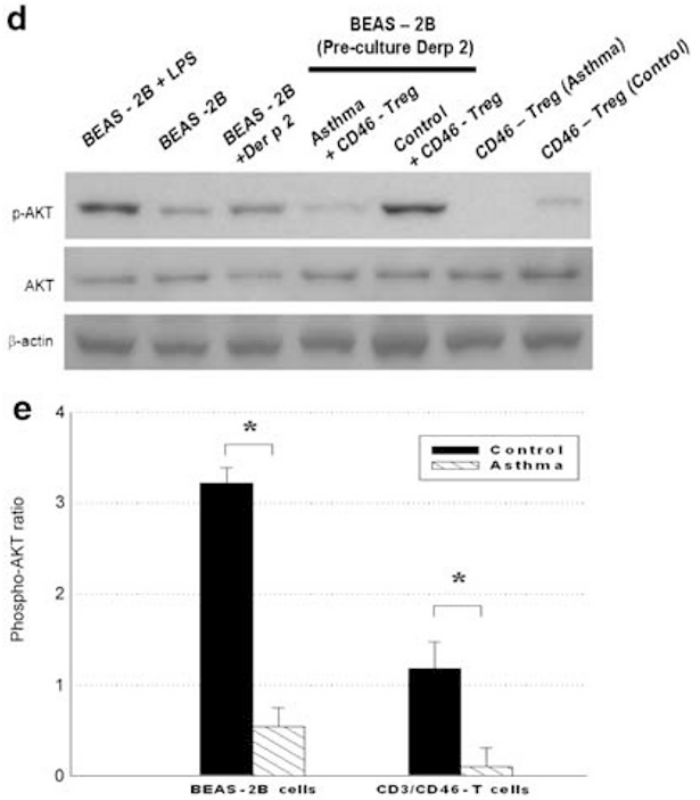

Figure 5 Decreased CCR4 expression and signaling transduction in CD3/CD46-induced CD4 ${ }^{+} \mathrm{T}$ cells in asthmatic patients. (a) Expression of homing chemokine receptors on $\mathrm{CD} 3 / \mathrm{CD} 46$-induced $\mathrm{CD} 4{ }^{+} \mathrm{T}$ cells were assessed by flow cytometry, representative data shown. (b) Experiments were performed in 30 paired samples (asthmatic and nonatopic group) ${ }^{*} P<0.05$. (c) Prestimulation BEAS-2B cells were incubated with Der $p 2$ for $2 \mathrm{~h}$, cultured with CD3/CD46activated Tregs (at ratio 1:1) in a six-well plate for $30 \mathrm{~min}$. Confluent BEAS-2B cells were separated from Tregs, epithelium purity examined by light microscope before analysis for ICAM expression. Co-cultured BEAS-2B cells labeled with epithelium marker (pan Cytokeratin) and ICAM-1 expression were determined by flow cytometry. ICAM- 1 activation decreased on BEAS-2B cells when cultured with CD3/CD46-activated Treg and BEAS-2B cells in asthmatics $(P<0.05)$; 30 paired samples had essentially identical results. (d) Nuclear proteins extracted from BEAS-2B and CD3/CD46-activated T cells were analyzed by western blot, using antiphospho-AKT mAb. AKT phosphorylation (e) decreased in BEAS-2B and CD3/CD46-activated Treg cells were noted in asthmatics $(P<0.05)$. Statistical data of experiments performed on 30 paired samples are shown.

\section{DISCUSSION}

The study shows percentage of CD46 surface expression on $\mathrm{CD}^{+}$Treg cells in bronchial tissue and peripheral blood significantly declining in asthmatics, compared with healthy controls. Diminished IL-10/granzyme B expression in CD3/ CD46-activated Tregs appeared in asthmatics. Decreased Der p 2-mediated chemotaxis between CD3/CD46-activated Treg and BEAS-2B cells in asthmatics are suggested by our data. CD3/CD46-mediated Tregs from asthmatics, similarly, showed lesser CCR4 expression and chemokine intracellular signaling proteins with AKT phosphorylation. Also, CD3/ CD46-activated Tregs suppress Der p 2-induced BEAS-2B cells inflammation via IL-10 secretion and cell contact inhibition. Taken together, results suggest CD3/CD46-activated Tregs' new potential therapeutic modality for allergic asthma.
Engaging chemokine receptors are proven to control TH2 cell chemotaxis toward alveoli or bronchial lumen to induce allergic inflammation. ${ }^{8,30}$ Chemokine receptor signaling that determines migration and homing of Treg cells into the lung is crucial for an effective interruption of airway inflammation in asthma. ${ }^{1-4,31,32}$ Chemokine receptors CCR4, CCR5, CCR7 and CCR8 are observed in Treg trafficking and function at sites of inflammation. ${ }^{33,34}$ Ahern $\mathrm{D}$ et al ${ }^{35}$ demonstrated downregulation of CCR4 expression upon allergen stimulation of $\mathrm{CD} 4{ }^{+} \mathrm{CD} 25^{+}$Tregs, precipitating failure to retain at sites of inflammation to attenuate T-cell activation. Data here reveals CD46 stimulation of Treg cells decreasing CCR4 expression in allergic asthma as critical in recruiting Tregs to epithelial surfaces to limit inflammation.

To probe the molecular mechanism for chemotactic responses in suppression of CD46-activated Tregs, cytoplasmic 
isoforms of CD46 (Cyt1 and Cyt2) mRNA expression from CD46-stimulated Tregs in asthma patients were examined. Researchers find that $\mathrm{CD} 3 / \mathrm{CD} 46$-activated $\mathrm{CD}^{+}{ }^{+} \mathrm{T}$ cells expressing Cyt 1 cytoplasmic domain produce IL-10 and initiate the chemotactic signaling pathway. ${ }^{12,36-39}$ This study confirmed a defect in IL-10-producing Tregs in asthmatics, ${ }^{28}$ by showing decreased Cyt1 expression; differential integrin/chemokine receptor expression, and lower AKT phosphorylation.

Although Tregs are reported in inflamed peripheral tissue, little is known about signals for recruiting Tregs to epithelial surfaces. ${ }^{40}$ This study analyzed homing properties of CD3/ CD46-induced Tregs adhering to bronchial epithelial cells under mite-induced inflammation. Der p 2-activated bronchial epithelial cells for recruiting CD3/CD46-induced Tregs to airways was further supported by induced expression of adhesion receptor ICAM-1 on BEAS-2B cells. Findings suggest ICAM-1 expression on BEAS-2B cells facilitating Treg: BEAS-2B cell interactions and contributing to Treg cell suppressive function. Evidence revealed ICAM-1 expression on epithelial cells as upregulated by IFN- $\gamma ;{ }^{41,42}$ IL-4 blocks ICAM-1 upregulation. ${ }^{43}$ CD46-activated Tregs decreasing IFN- $\gamma$ secretion in asthmatics may further support the above findings.

Bronchial epithelial cells yielding chemokines and proinflammatory signals in response to inhaled allergens relate to development of human asthma. ${ }^{44}$ Transcription factor, NF$\kappa \mathrm{B}$, has a key regulatory role in airway inflammation. Modulated NF- $\kappa$ B activation may provide therapeutic strategy to inhibit inflammatory mediators in asthma. ${ }^{45,46} \mathrm{To}$ address functional significance of epithelium-derived NF- $\kappa \mathrm{B}$ activation that cause allergic airway inflammation, recombinant Der $\mathrm{p} 2$ is proven to activate BEAS-2B cells inducing $\mathrm{NF} \kappa \mathrm{B}$ and producing inflammatory mediators. $\mathrm{CD} 3 / \mathrm{CD} 46-$ activated $\mathrm{CD}^{+}{ }^{+} \mathrm{T}$ cells from asthma subjects less to downregulate NF- $\kappa \mathrm{B} / \mathrm{p} 65$ expression in BEAS-2B cells may arise from defective IL-10 secretion. Some studies indicate IL-10 inhibiting NF- $\kappa \mathrm{B}$ translocation, thus relieving airway inflammation. ${ }^{5,47,48}$ IL-10-producing $\operatorname{Tr} 1$ cells have an important role in the pathogenesis and treatment of allergic asthma. ${ }^{28,49}$

Ni Choileain et $a l^{50}$ demonstrated surface CD46 as cleaved by a metalloproteinase upon T-cell activation. Herein, CD46 expression on $\mathrm{CD}^{+}{ }^{+} \mathrm{T}$ cells decreased in bronchial tissue of mite sensitive asthmatic patients, hinting CD46 surface downregulation has a role during T-cell activation.

In summary, evidence shows decreased IL-10/granzyme B, CCR4 expression and chemotactic signaling pathway in CD3/ CD46-activated Tregs from asthma patients can explain dysfunctional ability to suppress mite-induced airway epithelial cell inflammation. It becomes conceivable to design therapeutic strategies manipulating Treg recruitment to attain tolerance and suppress airway inflammation in allergic asthma.

Supplementary Information accompanies the paper on the Laboratory Investigation website (http://www.laboratoryinvestigation.org)

\section{ACKNOWLEDGEMENT}

This work was partially supported by grants from the National Science Council, Taiwan, ROC (NSC 100-2314-B-371 -005); and grants from

Changhua Christian Hospital.

\section{DISCLOSURE/CONFLICT OF INTEREST}

The authors declare no conflict of interest.

1. Ryanna K, Stratigou V, Safinia N, et al. Regulatory $T$ cells in bronchial asthma. Allergy 2009;64:335-347.

2. Akdis CA, Akdis M. Mechanisms and treatment of allergic disease in the big picture of regulatory T cells. J Allergy Clin Immunol 2009;123: 735-746.

3. Palomares O, Yaman G, Azkur AK, et al. Role of Treg in immune regulation of allergic diseases. Eur J Immunol 2010;40:1232-1240.

4. Kearley J, Robinson DS, Lloyd CM. CD4+CD25+ regulatory T cells reverse established allergic airway inflammation and prevent airway remodeling. J Allergy Clin Immunol 2008;122:617-624.

5. Tsai YG, Chiou YL, Chien JW, et al. Induction of IL-10+ CD4+CD25+ regulatory $\mathrm{T}$ cells with decreased NF-kappaB expression during immunotherapy. Pediatr Allergy Immunol 2010;21:e166-e173.

6. Bluestone JA, Abbas AK. Natural versus adaptive regulatory T-cells. Nat Rev Immunol 2003;3:253-257.

7. Hawrylowicz CM, O'Garra A. Potential role of interleukin-10-secreting regulatory T cells in allergy and asthma. Nat Rev Immunol 2005;5: 271-283.

8. Medoff BD, Thomas SY, Luster AD. T cell trafficking in allergic asthma: the ins and outs. Annu Rev Immunol 2008;26:205-232.

9. Wei S, Kryczek I, Zou W. Regulatory T-cell compartmentalization and trafficking. Blood 2006;108:426-431.

10. Hartl D, Koller B, Mehlhorn AT, et al. Quantitative and functional impairment of pulmonary CD4+CD25hi regulatory T cells in pediatric asthma. J Allergy Clin Immunol 2007;119:1258-1266.

11. Zhang $X, \mathrm{Köhl}$ J. A complex role for complement in allergic asthma. Expert Rev Clin Immunol 2010;6:269-277.

12. Marie $J C$, Astier AL, Rivailler $P$, et al. Linking innate and acquired immunity. Divergent role of CD46 cytoplasmic domains in T cell induced inflammation. Nat Immunol 2002;3:659-666.

13. Russell S. CD46: a complement regulator and pathogen receptor that mediates links between innate and acquired immune function. Tissue Antigens 2004;64:111-118.

14. Riley-Vargas RC, Gill DB, Kemper C, et al. CD46: expanding beyond complement regulation. Trends Immunol 2004;25:496-503.

15. Christmas SE, de la Mata Espinosa CT, Halliday D, et al. Levels of expression of complement regulatory proteins CD46, CD55 and CD59 on resting and activated human peripheral blood leucocytes. Immunology 2006;119:522-528.

16. Elward K, Griffiths M, Mizuno M, et al. CD46 plays a key role in tailoring innate immune recognition of apoptotic and necrotic cells. J Biol Chem 2005;280:36342-36354.

17. Kemper C, Chan AC, Green JM, et al. Activation of human CD4+ cells with $\mathrm{CD} 3$ and CD46 induces a T-regulatory cell 1 phenotype. Nature 2003;421:388-392.

18. Fuchs A, Atkinson JP, Fremeaux-Bacchi V, et al. CD46-induced human Treg enhance B-cell responses. Eur J Immunol 2009;39:3097-3109.

19. Longhi MP, Harris CL, Morgan BP, et al. Holding T cells in check-a new role for complement regulators? Trends Immunol 2006;27:102-108.

20. Kemper C, Verbsky JW, Price JD, et al. T-cell stimulation and regulation: with complements from CD46. Immunol Res 2005;32:31-43.

21. Grossman WJ, Verbsky JW, Tollefsen BL, et al. Differential expression of granzymes $A$ and $B$ in human cytotoxic lymphocyte subsets and $T$ regulatory cells. Blood 2004;104:2840-2848.

22. Sánchez A, Feito MJ, Rojo JM. CD46-mediated costimulation induces a Th1-biased response and enhances early TCR/CD3 signaling in human CD4+ T lymphocytes. Eur J Immunol 2004;34:2439-2448.

23. Kurita-Taniguchi M, Fukui $A$, Hazeki $K$, et al. Functional modulation of human macrophages through CD46 (measles virus receptor) production of IL-12 p40 and nitric oxide in association with recruitment of protein-tyrosine phosphatase SHP-1 to CD46. J Immunol 2000; 165:5143-5152. 
24. Alford SK, Longmore GD, Stenson WF, et al. CD46-induced immunomodulatory CD4+ T cells express the adhesion molecule and chemokine receptor pattern of intestinal T cells. J Immunol 2008;181:2544-2555.

25. Astier AL, Meiffren G, Freeeman S, et al. Alterations in CD46-mediated Tr1 regulatory $T$ cells in patients with multiple sclerosis. J Clin Invest 2006;116:3252-3257.

26. Astier AL. T-cell regulation by CD46 and its relevance in multiple sclerosis. Immunology 2008;124:149-154.

27. Vaknin-Dembinsky A, Murugaiyan G, Hafler DA, et al. Increased IL-23 secretion and altered chemokine production by dendritic cells upon CD46 activation in patients with multiple sclerosis. J Neuroimmuno 2008;195:140-145.

28. Xu YQ, Gao YD, Yang J, et al. A defect of CD4+CD25+ regulatory $T$ cells in inducing interleukin-10 production from CD4+ T cells under CD46 costimulation in asthma patients. J Asthma 2010;47:367-373.

29. Wang HH, Lee TY, Lin CY. Integrins mediate adherence and migration of $\mathrm{T}$ lymphocytes on human peritoneal mesothelial cells. Kidney Int 2008;74:808-816.

30. Wardlaw T, Guillen C, Morgan A. Mechanisms of T cell migration to the lung. Clin Exp Allergy 2005;35:4-7.

31. Kocks JR, Davalos-Misslitz AC, Hintzen G, et al. Regulatory T cells interfere with the development of bronchus-associated lymphoid tissue. J Exp Med 2007;204:723-734.

32. Nguyen KD, Vanichsarn C, Fohner A, et al. Selective deregulation in chemokine signaling pathways of CD4+CD25(hi)CD127(lo)/(-) regulatory $T$ cells in human allergic asthma. J Allergy Clin Immunol 2009;123:933-939.

33. Lee $\mathrm{HY}$, Hong $\mathrm{YK}, \mathrm{Yun} \mathrm{HJ}$, et al. Altered frquency and migration capacity of CD4+CD25+ regulatory $T$ cells in systemic lupus erythematosus. Rheumatology 2008;47:789-794.

34. lellem A, Mariani M, Lang $\mathrm{R}$, et al. Unique chemotactic response profile and specific expression of chemokine receptors CCR4 and CCR8 by CD4(+)CD25(+) regulatory T cells. J Exp Med 2001;194:847-853.

35. Ahern D, Lloyd CM, Robinson DS, et al. Chemokine responsiveness of CD4+ CD25+ regulatory and CD4+ CD25- T cells from atopic and nonatopic donors. Allergy 2009;64:1121-1129.

36. Wang G, Liszewski MK, Chan AC, et al. Membrane cofactor protein (MCP; CD46): isoform-specific tyrosine phosphorylation. J Immunol 2000;64:1839-1846.

37. Ludford-Menting MJ, Thomas SJ, Crimeen B, et al. A functional interaction between CD46 and DLG4: a role for DLG4 in epithelial polarization. J Biol Chem 2002;277:4477-4484.

38. Zaffran $Y$, Destaing $O$, Roux A, et al. CD46/CD3 costimulation induces morphological changes of human $T$ cells and activation of Vav, Rac, and extracellular signal-regulated kinase mitogen-activated protein kinase. J Immunol 2001;167:6780-6785.

39. Oliaro J, Pasam A, Waterhouse NJ, et al. Ligation of the cell surface receptor, CD46, alters $\mathrm{T}$ cell polarity and response to antigen presentation. Proc Natl Acad Sci USA 2006;103:18685-18690.

40. Eksteen B, Miles A, Curbishley SM, et al. Epithelial inflammation is associated with CCL28 production and the recruitment of regulatory $T$ cells expressing CCR10. J Immunol 2006;177:593-603.

41. Defazio G, Trojano M, Ribatti D, et al. ICAM-1 expression and fluid phase endocytosis of cultured brain microvascular endothelial cells following exposure to interferon beta-1a and TNFalpha. J Neuroimmunol 1998;88:13-20.

42. Kohm AP, Miller SD. Role of ICAM-1 and P-selectin expression in the development and effector function of CD4+CD25+regulatory $T$ cells. J Autoimmun 2003;21:261-271.

43. Kapiotis S, Quehenberger P, Sengoelge G, et al. Modulation of pyrogen-induced upregulation of endothelial cell adhesion molecules (ICAMs) by interleukin-4: transcriptional mechanisms and ICAMshedding. Circ Shock 1994;43:18-25.

44. Janssen-Heininger YM, Poynter ME, Aesif SW, et al. Nuclear factor kappaB, airway epithelium, and asthma: avenues for redox control. Proc Am Thorac Soc 2009;6:249-255.

45. Osterlund C, Grönlund H, Polovic N, et al. The non-proteolytic house dust mite allergen Der p 2 induce NF-kappaB and MAPK dependent activation of bronchial epithelial cells. Clin Exp Allergy 2009;39: 1199-1208.

46. Wong $\mathrm{CK}$, $\mathrm{Li} \mathrm{ML}$, Wang $\mathrm{CB}$, et al. House dust mite allergen Der $\mathrm{p} 1$ elevates the release of inflammatory cytokines and expression of adhesion molecules in co-culture of human eosinophils and bronchial epithelial cells. Int Immunol 2006;18: 1327-1335.

47. Kearley J, Barker JE, Robinson DS, et al. Resolution of airway inflammation and hyperreactivity after in vivo transfer of CD4+ CD25+ regulatory $\mathrm{T}$ cells is interleukin 10 dependent. J Exp Med 2005;202:1539-1547.

48. Yuri P, Rubtsov P, Rasmussen JP, et al. Regulatory $\mathrm{T}$ cell-derived interleukin- 10 limits inflammation at environmental interfaces. Immunity 2008;28:546-558.

49. Martinez-Forero I, Garcia-Munoz R, Martinez-Pasamar S, et al. IL-10 suppressor activity and ex vivo Tr1 cell function are impaired in multiple sclerosis. Eur J Immunol 2008;38:576-586.

50. Ni Choileain S, Weyand NJ, Neumann C, et al. The dynamic processing of CD46 intracellular domains provides a molecular rheostat for $\mathrm{T}$ cell activation. PLoS One 2011;6:e16287. 